\title{
Total Synthesis of Ningalin D
}

\author{
Akiyuki Hamasaki, Jeffrey M. Zimpleman, Inkyu Hwang, and Dale L. Boger* \\ Department of Chemistry and the Skaggs Institute for Chemical Biology, The Scripps Research \\ Institute, 10550 North Torrey Pines Road, La Jolla, California 92037
}

\begin{abstract}
A concise (9 step) and effective (19\% overall yield) total synthesis of ningalin D (1a) is disclosed and is based on a key 1,2,4,5-tetrazine $\rightarrow$ 1,2-diazine $\rightarrow$ pyrrole Diels-Alder strategy to assemble a fully substituted pyrrole core central to its structure. Additional highlights of the synthesis include a double Dieckmann condensation to introduce the $\mathrm{C}$ and $\mathrm{D}$ aryl rings enlisting substituents judiciously placed on the dienophile and intrinsic to the widely used tetrazine 2, a highly effective Suzuki coupling of the resulting $\mathrm{C}$ and $\mathrm{D}$ phenol triflates for introduction of the sterically demanding $\mathrm{F}$ and $\mathrm{G}$ aryl rings, and an unusually effective formal oxidative decarboxylation reaction cascade initiated by a Curtius rearrangement to directly provide the biphenylene quinone methide found imbedded in the structure of ningalin D. The cytotoxic and multidrug resistance (MDR) reversal activity of ningalin $\mathrm{D}$, its derivatives, and the key synthetic intermediates are detailed.
\end{abstract}

First isolated in 1997 by Fenical and Kang, ${ }^{1}$ the ningalins constitute a family of structurally interesting and biologically active marine natural products. By far, the most complex of these is ningalin D (1a) incorporating a biphenylene quinone methide superimposed on a now oxidized pentasubstituted pyrrole core that characterizes this class of natural products (Figure 1). To our knowledge, the only closely related natural product disclosed to date is purpurone (1b), ${ }^{2}$ an inhibitor of ATP-citrate lyase whose name reflects the purple color of the natural products and the sponges from which both $\mathbf{1 a}$ and $\mathbf{1 b}$ were isolated (Didemnum sp. and Iotrochota sp., respectively). In the course of developing total syntheses of the simpler members of the ningalin family, ${ }^{3}$ we disclosed several derivatives that possess potent P-gp inhibitory activity, ${ }_{3}^{3}$ effective multidrug resistance (MDR) reversal properties in cellular functional assays, ${ }^{3-5}$ and efficacious (potentiation/resensitization) in vivo antitumor activity against sensitive and resistant tumors upon coadministration with antitumor therapeutics (vinblastine, taxol) in xenograph animal models. ${ }^{6}$ Although such derivatives lack intrinsic cytotoxic activity themselves, they resensitize MDR tumors and hypersensitize sensitive tumors to conventional therapeutics through inhibition of the overexpressed or constituitive drug effux pump P-gp. ${ }^{3-6}$

As a consequence of these biological observations with the simpler ningalin derivatives and because of the intrinsically interesting structure of ningalin $\mathrm{D}$, we have pursued and herein detail the first total synthesis of ningalin $\mathrm{D}$ in studies that complement the only other reported efforts in the area, a biomimetic total synthesis of purpurone disclosed by Steglich. ${ }^{7}$ Key elements of the concise and nonobvious approach include an inverse electron demand heterocyclic azadiene Diels-Alder reaction (1,2,4,5-tetrazine $\rightarrow$ 1,2-diazine) followed by a

E-mail: boger@scripps.edu.

Publisher's Disclaimer: This PDF receipt will only be used as the basis for generating PubMed Central (PMC) documents. PMC documents will be made available for review after conversion (approx. 2-3 weeks time). Any corrections that need to be made will be done at that time. No materials will be released to PMC without the approval of an author. Only the PMC documents will appear on PubMed Central -- this PDF Receipt will not appear on PubMed Central. 
reductive ring contraction of the resultant 1,2-diazine affording the fully substituted pyrrole core central to the structure of $\mathbf{1}$ (Figure 1). A double Dieckmann cyclization enlisting substituents judiciously placed on the dienophile $\left(-\mathrm{CH}_{2} \mathrm{CO}_{2} \mathrm{Me}\right)$ and intrinsic to the widely used tetrazine $2\left(-\mathrm{CO}_{2} \mathrm{Me}\right)$ was used to close the $\mathrm{C}$ and $\mathrm{D}$ aryl rings, the sterically demanding $\mathrm{F}$ and $\mathrm{G}$ aryl rings were introduced enlisting a highly effective Suzuki coupling onto the corresponding $\mathrm{C}$ and $\mathrm{D}$ ring phenol triflates, and an unusually effective formal oxidative decarboxylation reaction cascade initiated by a Curtius rearrangement was discovered to directly provide the biphenylene quinone methide of ningalin $\mathrm{D}$.

Preparation of the symmetrical alkyne $\mathbf{3}$, a suitably substituted electron-rich dienophile for Diels-Alder cycloaddition with $\mathbf{2}$, was accomplished in two steps from commercially available 2-bromo-4,5-dimethoxyacetonitrile. ${ }^{8 \mathrm{a}}$ Conversion of the nitrile to the known methyl ester ${ }^{9}$ (cat. $\mathrm{H}_{2} \mathrm{SO}_{4}, \mathrm{MeOH}, 90 \%$ ) followed by a double Stille coupling with 1,2-bis(tributylstannyl) acetylene $\left(0.05\right.$ equiv of $\left(\mathrm{Ph}_{3} \mathrm{P}\right)_{4} \mathrm{Pd}$, toluene, $\left.110{ }^{\circ} \mathrm{C}, 6 \mathrm{~h}, 71-80 \%\right)$ provided ready access to 3. The key $[4+2]$ cycloaddition of $\mathbf{3}$ with dimethyl 1,2,4,5-tetrazine-3,6-dicarboxylate (2) ${ }^{10}$ proceeded smoothly in refluxing toluene $\left(110^{\circ} \mathrm{C}\right)$ to provide the symmetrical 1,2-diazine 4 in superb conversions (87\%) and was followed by a subsequent reductive ring contraction reaction effected by treatment with $\mathrm{Zn} / \mathrm{TFA}$ ( 30 equiv of $\mathrm{Zn}$, TFA, $25^{\circ} \mathrm{C}, 7 \mathrm{~h}, 64 \%$ ) to provide the pyrrole $\mathbf{5}$ (Scheme 1). Although such reductive ring contraction reactions are typically conducted with $\mathrm{Zn} / \mathrm{HOAc},{ }^{11}$ we have disclosed that the overall reaction cascade is much faster (4-7 vs $24 \mathrm{~h}$ for $4,25^{\circ} \mathrm{C}$ ) with $\mathrm{Zn} / \mathrm{TFA}^{12}$ and often much cleaner (Scheme 2).

$\mathrm{N}$-Alkylation of 5 with $\mathbf{6}^{8 \mathrm{~b}}$ (3 equiv, 3 equiv of $\mathrm{CsCO}_{3}, 13 \mathrm{DMF}, 60{ }^{\circ} \mathrm{C}, 2 \mathrm{~h}, 92 \%$ ) afforded 7 and set the stage for introduction of the aryl $\mathrm{C}$ and D rings via a double Dieckmann condensation which was effected by treatment of 7 with $\mathrm{NaH}$ ( 6 equiv, DMF, $25^{\circ} \mathrm{C}, 15 \mathrm{~h}$, $81 \%$ ) cleanly providing $\mathbf{8}$. Notably, the second of the two Dieckmann condensations proceeds more slowly than the first requiring adoption of a sterically encumbered coplanar arrangement of the $\mathrm{A}$ and $\mathrm{B}$ aryl rings. Conversion of the bisphenol $\mathbf{8}$ to the corresponding bis triflate 9 ( 5 equiv of $\mathrm{Tf}_{2} \mathrm{O}$, py- $\left.\mathrm{CH}_{2} \mathrm{Cl}_{2}(1: 1), 0-25{ }^{\circ} \mathrm{C}, 2 \mathrm{~h}, 92 \%\right)$ preceded an unusually effective double Suzuki coupling with 10 ( 0.1 equiv of $\left(\mathrm{Ph}_{3} \mathrm{P}\right)_{4} \mathrm{Pd}, 2.2$ equiv of $\mathrm{LiCl}, 1 \mathrm{M}$ aq. $\mathrm{K}_{2} \mathrm{CO}_{3}-\mathrm{DME}$, $\left.80{ }^{\circ} \mathrm{C}, 15 \mathrm{~h}, 88 \%\right)$ to provide 11 . Notably, the inclusion of $\mathrm{LiCl}$ (2.2 equiv) in the reaction mixture ${ }^{14}$ was key to the superb conversions which in its absence proved much lower $(0-35 \%)$.

The final conversion of $\mathbf{1 1}$ to the penultimate ningalin $\mathrm{D}$ precursor required conversion of the aryl esters to phenols and was anticipated to arise from Baeyer-Villiger oxidation of the corresponding ketones, or a benzylic hydroxperoxide rearrangement of the corresponding secondary or tertiary alcohols. Although not investigated in detail, each of these proved problematic to implement due to the sterically hindered nature of the site. However, hydrolysis of diester $\mathbf{1 1}$ to the dicarboxylic acid $\mathbf{1 2}$ could be effected cleanly with anhydrous hydroxide ${ }^{15}$ (26 equiv of $t$-BuOK, 8 equiv of $\mathrm{H}_{2} \mathrm{O}$, DMSO, $80^{\circ} \mathrm{C}, 24 \mathrm{~h}, 84 \%$ ) whereas typical saponification conditions ( $2 \mathrm{~N}$ aq. $\mathrm{KOH}$, reflux, $48 \mathrm{~h}$ ) failed to touch $\mathbf{1 1}$. Characteristic of the congested nature of the site, attempts to prepare the acid chloride of $\mathbf{1 2}\left(\mathrm{SOCl}_{2}-\mathrm{DMF}\right.$, $\mathrm{CH}_{2} \mathrm{Cl}_{2}, 25{ }^{\circ} \mathrm{C}, 4 \mathrm{~h}$ ) resulted in clean conversion to $\mathbf{1 5}(70 \%)$ derived from a facile double Friedel-Crafts acylation of the proximal and activated $\mathrm{F}$ and $\mathrm{G}$ aryl rings, eq. 1.

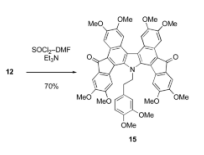

Although several direct conversions of $\mathbf{1 2}$ to permethyl ningalin D were examined including a carboxy inversion reaction and a $\mathrm{Pb}(\mathrm{OAc})_{4}$ catalyzed oxidative decarboxylation reaction, the 
surprisingly most straightforward approach proved to be initiated by Curtius rearrangement of the dicarboxylic acid $\mathbf{1 2}$ which was anticipated to provide the corresponding diamine. Under the conditions of a modified Curtius rearrangement and in situ hydrolysis of the resulting isocyanate (5 equiv of DPPA, ${ }^{16} 5$ equiv of $i$ - $\mathrm{Pr}_{2} \mathrm{NEt}, \mathrm{CH}_{2} \mathrm{Cl}_{2}, 25^{\circ} \mathrm{C}, 15-20 \mathrm{~h}$; then $\mathrm{H}_{2} \mathrm{O}-\mathrm{THF}$, air atmosphere, reflux, $90 \mathrm{~h} ; 70 \% \mathbf{1 3}$ ), we observed and subsequently adopted conditions that optimized the conversion directly to permethyl ningalin $\mathrm{D}(\mathbf{1 3})$. Thus, a remarkably facile in situ oxidation of the expected diamine to the biphenylene quinodiimide and subsequent imine hydrolysis were observed to occur under the reaction conditions providing 13 directly in superb overall conversions (70\%) for the seven transformations from the dicarboxylic acid $\mathbf{1 2}$ (Scheme 3). Exhaustive deprotection of $\mathbf{1 3}$ ( 15 equiv of $\mathrm{BBr}_{3}, \mathrm{CH}_{2} \mathrm{Cl}_{2},-78$ to $25^{\circ} \mathrm{C}, 16 \mathrm{~h}, 96 \%$ ) requiring the removal of ten methyl ethers cleanly provided ningalin $\mathrm{D}(\mathbf{1 a})$ identical in all respects with authentic material. ${ }^{1}$ Acetylation of $1 \mathrm{a}\left(\mathrm{Ac}_{2} \mathrm{O}\right.$, py, $\left.25^{\circ} \mathrm{C}, 3 \mathrm{~h}, 98 \%\right)$ provided ningalin $\mathrm{D}$ decaacetate (14) which also displayed properties identical in all respects with those reported for authentic material. ${ }^{1}$

With 1a, 13, and the precursor intermediates in hand, they were examined alongside permethyl ningalin $\mathrm{B}(\mathbf{1 6})^{3 \mathrm{~b}}$ in assays to establish their intrinsic cytotoxic activity (Table 1 , an undesired property) and their ability to reverse multidrug resistance ${ }^{17}$ resensitizing a resistant cell line to front line antitumor drugs (Table 2). Ningalin $\mathrm{D}(\mathbf{1 a})$, permethyl ningalin $\mathrm{D}(\mathbf{1 3})$, and ningalin $\mathrm{D}$ decaacetate (14) exhibited modest cytotoxic activity against a murine leukemia cell line $\left(\mathrm{L} 1210, \mathrm{IC}_{50}=1-7 \mu \mathrm{M}\right)$ and a parental human colon cancer cell line $\left(\mathrm{HCT} 116, \mathrm{IC}_{50}=1-70\right.$ $\mu \mathrm{M})$. Each of the modestly active compounds contain the embedded biphenylene quinone methide characteristic of ningalin D, suggesting their use as MDR reversal agents, unlike 16, $3 \mathrm{~b}$ would be complicated by this secondary cytotoxic activity.

Pertinent to our interests, the compounds were examined against a resistant HCT116 cell line that embodies the MDR phenotype via overexpression of P-glycoprotein (P-gp). This cell line, HCT116/VM46 which is resistant to both vinblastine $\left(\mathrm{IC}_{50}=100 \mathrm{vs} 7 \mathrm{nM}\right.$ for parental HCT116) and doxorubicin $\left(\mathrm{IC}_{50}=900 \mathrm{vs} 70 \mathrm{nM}\right.$ for parental HCT116) was treated with each of the ningalin derivatives at $1 \mu \mathrm{M}$ and the $\mathrm{IC}_{50}$ established for coadministered vinblastine or doxorubicin (Table 2). Prototypical MDR reversal agents are usually examined at higher concentrations (e.g., 7.5-10 $\mu \mathrm{M}$ verapamil) and few lead series exhibit effective properties when examined at $1 \mu \mathrm{M}$ as detailed herein. ${ }^{17}$ Under these stringent conditions, ningalin D (1a) as well as ningalin D decaacetate (14) were inactive, whereas permethyl ningalin $\mathrm{D}(\mathbf{1 3})$ effectively resensitized the resistant HCT116/VM46 cell line to vinblastine $\left(\mathrm{IC}_{50}=8.5 \mathrm{nM}\right.$, $80 \%$ reversion) and doxorubicin ( $\mathrm{IC}_{50} 100 \mathrm{nM}, 70 \%$ reversion). This behavior of the hydrophobic permethyl ether derivative of the natural product versus the natural product itself (13 vs 1a) is analogous to distinctions we observed earlier with 16 (permethyl ningalin B, Figure 2) versus the inactive natural product ningalin B (free phenols). ${ }^{3 b}$ More significantly and of the derivatives that lack the biphenylene quinone methide and its undesired accompanying cytotoxic activity, $\mathbf{1 1}$ and especially $\mathbf{1 5}$ were found to be active, $\mathbf{8}$ exhibited an intermediate level of activity, and both $\mathbf{7}$ and $\mathbf{1 2}$ were inactive. The relative inactivity of the polar derivatives 8,12 , and $\mathbf{7}$ was not surprising and the MDR reversal activity of $\mathbf{1 1}$ expectedly approached that of 16. More unexpectedly, the inadvertently prepared Friedel-Crafts acylation byproduct 15 proved to be a potent MDR reversal agent matching the efficacy of 16 at $1 \mu \mathrm{M}$.

Notably, each of the active compounds incorporate three hydrophobic domains that characterize the P-gp binding pharmacophore models, ${ }^{18}$ but unique in ningalin series of MDR reversal agents is the lack of a basic amine central to the structure. As such, they not only constitute efficacious compounds exhibiting unusually potent MDR reversal activity for a lead series, but they also depart from structural features considered central to common pharmacophore models of P-gp binding. 


\section{Supplementary Material}

Refer to Web version on PubMed Central for supplementary material.

\section{Acknowledgements}

We gratefully acknowledge the financial support of the National Institutes of Health (CA42056) and The Skaggs Institute for Chemical Biology. JMZ was a Skaggs predoctoral fellow.

\section{References and Notes}

1. Kang H, Fenical W. J Org Chem 1997;62:3254. [PubMed: 11671712]

2. Chan GW, Francis T, Thureen DR, Offen PH, Pierce NJ, Westley JW, Johnson RK, Faulkner DJ. J Org Chem 1993;58:2544.

3. a Boger DL, Boyce CW, Labroli MA, Sehon CA, Jin Q. J Am Chem Soc 1999;121:54. b Boger DL, Soenen DR, Boyce CW, Hedrick MP, Jin Q. J Org Chem 2000;65:2479. [PubMed: 10789460] For additional disclosures of ningalin total syntheses: ningalin B c Iwao M, Takeuchi T, Fujikawa N, Fukuda T, Ishibashi F. Tetrahedron Lett 2003;44:4443. d Bullington JL, Wolff R, Jackson PF. J Org Chem 2002;67:9439. [PubMed: 12492350] Ningalin C: e Namsaaid A, Ruchirawat S. Org Lett 2002;4:2633. [PubMed: 12153196] and ref 7

4. Soenen DR, Hwang I, Hedrick MP, Boger DL. Bioorg Med Chem Lett 2003;13:1777. [PubMed: 12729663]

5. Tao H, Hwang I, Boger DL. Bioorg Med Chem Lett 2004;14:5979. [PubMed: 15546712]

6. Chou TC, Guan Y, Soenen DR, Danishefsky SJ, Boger DL. Cancer Chemother Pharmacol. 2005in press

7. Peschko C, Steglich W. Tetrahedron Lett 2000;41:9477.

8. (a) Trans-World Chemicals, Rockville, MD. (b) Sigma-Aldrich library of rare chemicals (commercial) or prepared from the corresponding alcohol (Aldrich): $\mathrm{I}_{2}, \mathrm{Ph}_{3} \mathrm{P}$, imidazole, $\mathrm{CH}_{2} \mathrm{Cl}_{2}, 96 \%$

9. Ambrose R, von Angerer S, Weigrebe W. Arch Pharm 1988;321:481.

10. a Boger DL, Panek JS, Patel M. Org Syn 1992;70:79. b Boger DL, Panek JS, Coleman RS, Sauer J, Huber FX. J Org Chem 1985;50:5377.

11. a Boger DL, Coleman RS, Panek JS, Yohannes D. J Org Chem 1984;49:4405. Reviews: b Boger DL. Tetrahedron 1983;39:2869. c Boger DL. Chem Rev 1986;86:781.

12. Boger DL, Patel M. J Org Chem 1988;53:1405.

13. Bullington JL, Wolff RR, Jackson PF. J Org Chem 2002;67:9439. [PubMed: 12492350]

14. Huth A, Beetz I, Schumann I. Tetrahedron 1989;45:6679.

15. a Chang FC, Wood NF. Tetrahedron Lett 1964:2969. b Gassman PG, Schenk WN. J Org Chem 1977;42:918.

16. Ninomiya K, Shioiri T, Yamada S. Tetrahedron 1974;30:2151.

17. Reviews: a Robert J, Jarry C. J Med Chem 2003;46:4805. [PubMed: 14584929] b Wiese M, Pajeva IK. Curr Med Chem 2001;8:685. [PubMed: 11281849]

18. a Pearce HL, Safa AR, Bach NJ, Winter MA, Cirtain MC, Beck WT. Proc Natl Acad Sci USA 1989;86:5128. [PubMed: 2567994]Pearce HL, Winter MA, Beck WT. Adv Enzyme Reg 1990;30:357. b Garrigues A, Loisau N, Delaforge M, Ferte J, Garrigos M, Andre F, Orlowski S. Mol Pharmacol 2002;61:1288. [PubMed: 12435795] c Ekins S, Kim RB, Leake BF, Dantzig AH, Schuetz EG, Lan LB, Yasuda K, Shepard RL, Winter MA, Schuetz JD, Wikel JH, Wrighton SA. Mol Pharmacol 2002;61:964, 974. [PubMed: 11961113] d Pajeva IK, Wiese M. J Med Chem 2002;45:5671. [PubMed: 12477351] 


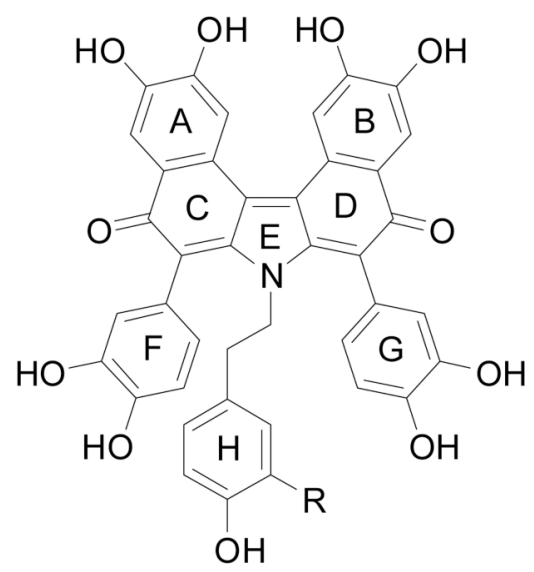

1a, $\mathrm{R}=\mathrm{OH}$ (Ningalin D)

1b, $\mathrm{R}=\mathrm{H}$ (Purpurone)
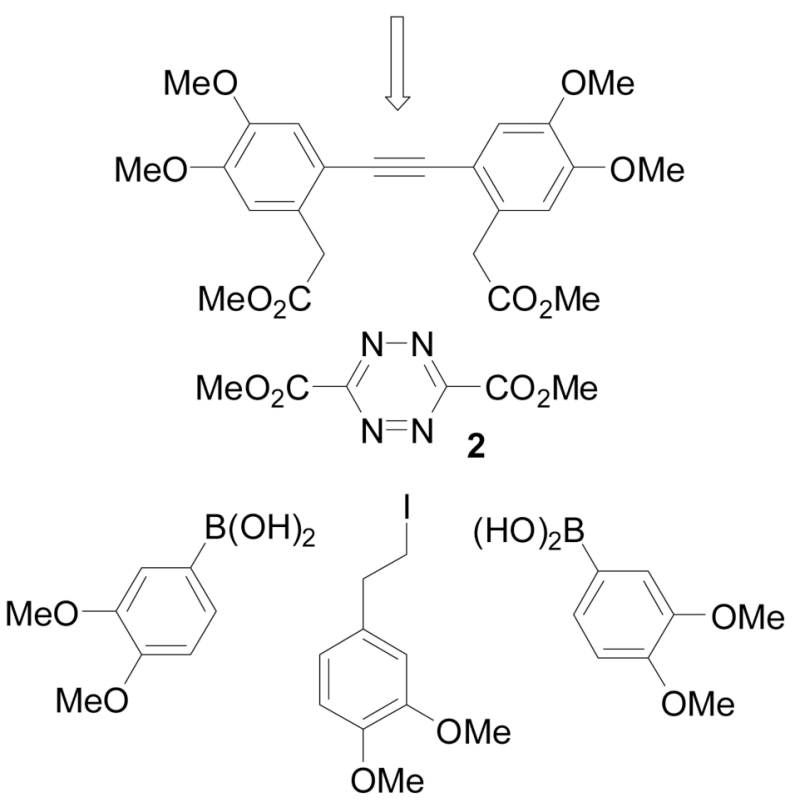

Figure 1.

Ningalin D and retrosynthetic analysis. 


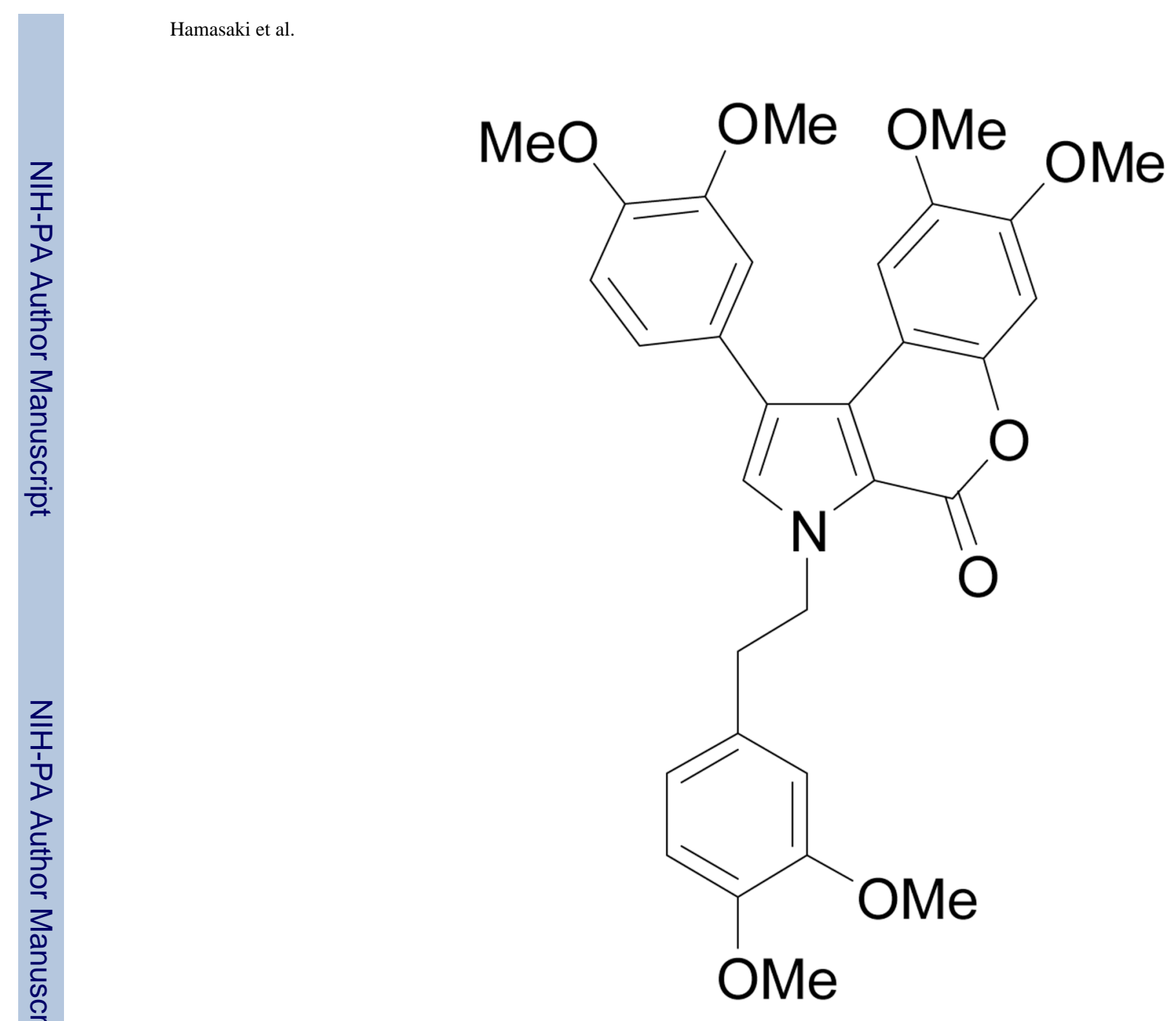

Figure 2.

Permethyl ningalin B. 

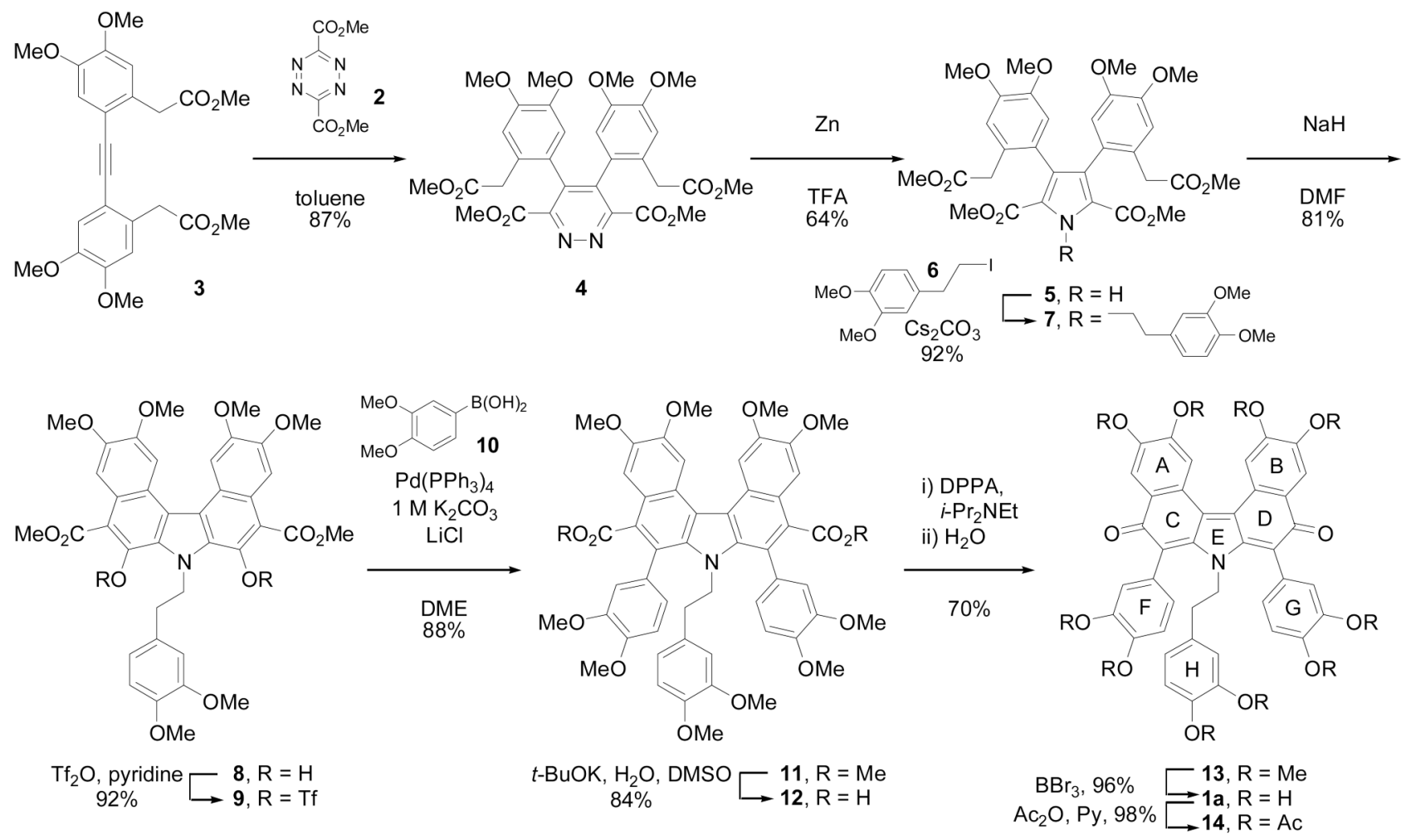

\section{Scheme 1.}

Total synthesis of ningalin D. 


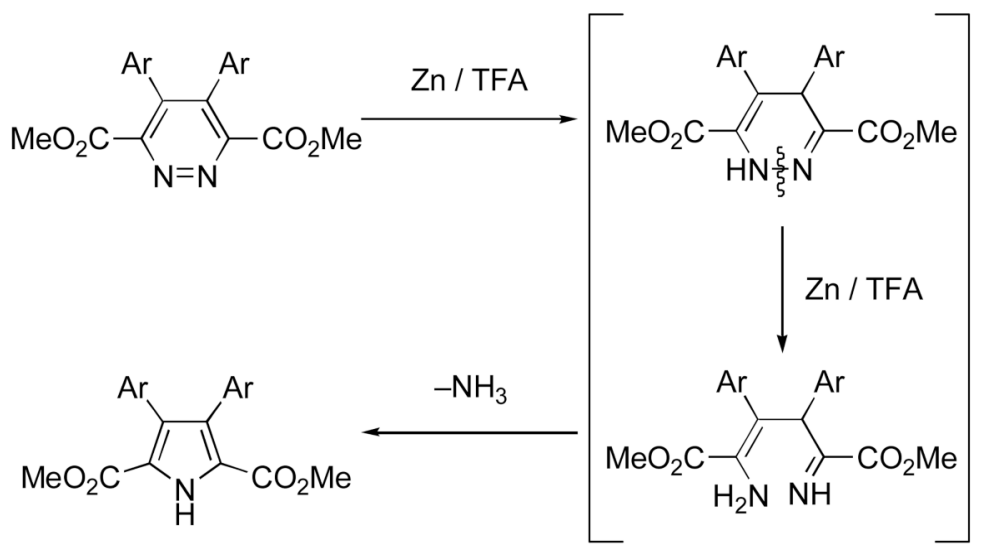

Scheme 2.

Reductive ring contraction. 


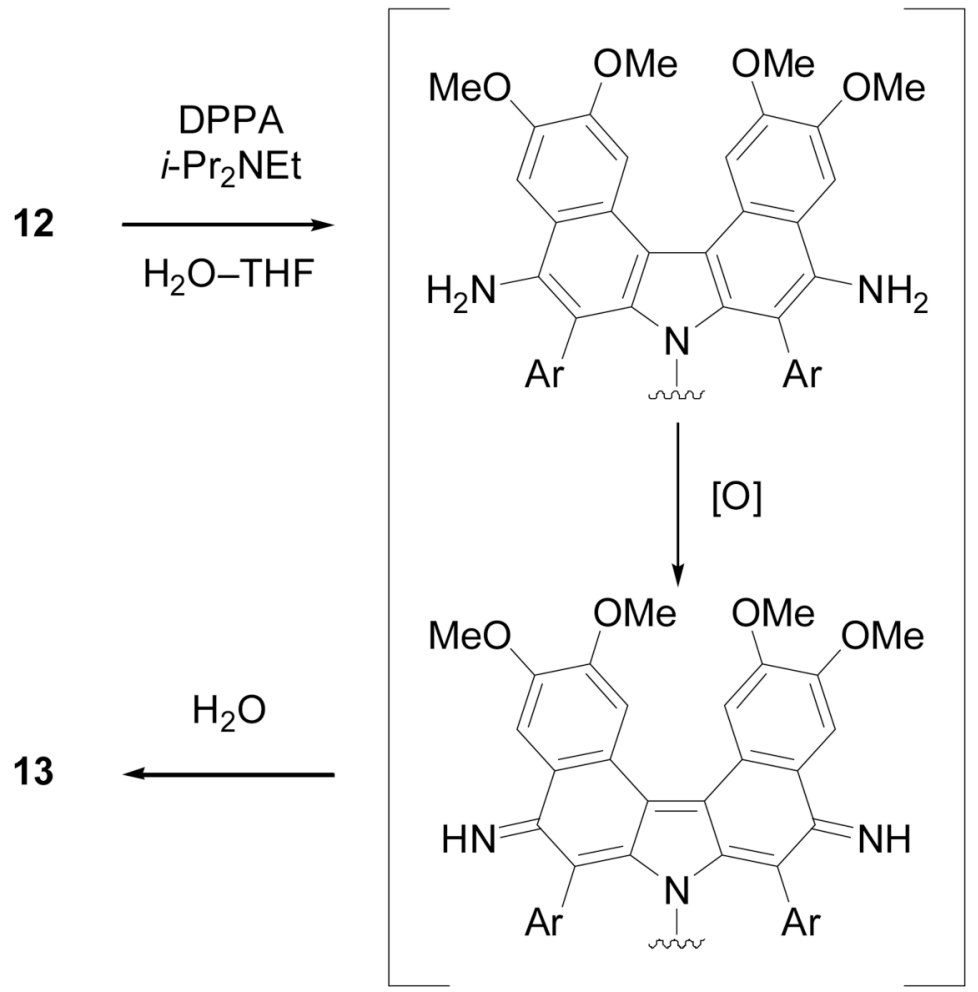

Scheme 3.

Oxidative decarboxylation reaction. 
Table 1

Cytotoxic Activity.

\begin{tabular}{|c|c|c|}
\hline \multirow{2}{*}{ Compound } & \multicolumn{2}{|c|}{$\mathrm{IC}_{50}(\mu \mathrm{M})$} \\
\hline & L1210 & HCT116 \\
\hline $1 a$ & 7 & 70 \\
\hline 7 & $>100$ & $>100$ \\
\hline 8 & $>100$ & $>100$ \\
\hline 11 & $>100$ & $>100$ \\
\hline 12 & $>100$ & $>100$ \\
\hline 13 & 1 & 1 \\
\hline 14 & 7 & 6 \\
\hline 15 & $>100$ & $>100$ \\
\hline 16 & $>100$ & $>100$ \\
\hline vinblastine & 0.007 & 0.007 \\
\hline doxorubicin & 0.06 & 0.07 \\
\hline
\end{tabular}


Table 2

MDR Activity.

\begin{tabular}{|c|c|c|}
\hline \multirow{2}{*}{$\begin{array}{l}\text { Compound } \\
\qquad(1 \mu \mathrm{M})\end{array}$} & \multicolumn{2}{|c|}{ HCT116/VM46 IC I0 $_{5 M}(\mathrm{nM})$} \\
\hline & Vinblastine (\%) ${ }^{a}$ & Doxorubicin $(\%)^{a}$ \\
\hline $\begin{array}{c}\text { none } \\
1 \mathrm{a} \\
7 \\
8 \\
11 \\
12 \\
13 \\
14 \\
15 \\
16\end{array}$ & $\begin{array}{r}100 \\
100(0 \%) \\
100(0 \%) \\
10(70 \%) \\
8.5(82 \%) \\
100(0 \%) \\
8.5(82 \%) \\
100(0 \%) \\
7(100 \%) \\
7(100 \%)\end{array}$ & $\begin{array}{r}900 \\
900(0 \%) \\
750(8 \%) \\
330(21 \%) \\
90(80 \%) \\
1000(0 \%) \\
100(70 \%) \\
900(0 \%) \\
90(80 \%) \\
90(80 \%)\end{array}$ \\
\hline
\end{tabular}

$a_{\%}$ Reversion, parental HCT116 IC50 for vinblastine $=7 \mathrm{nM}$ and doxorubicin $=70 \mathrm{nM}$ 